\title{
A Flow System for Enantioselective Carbonyl Ylide Cycloaddition
}

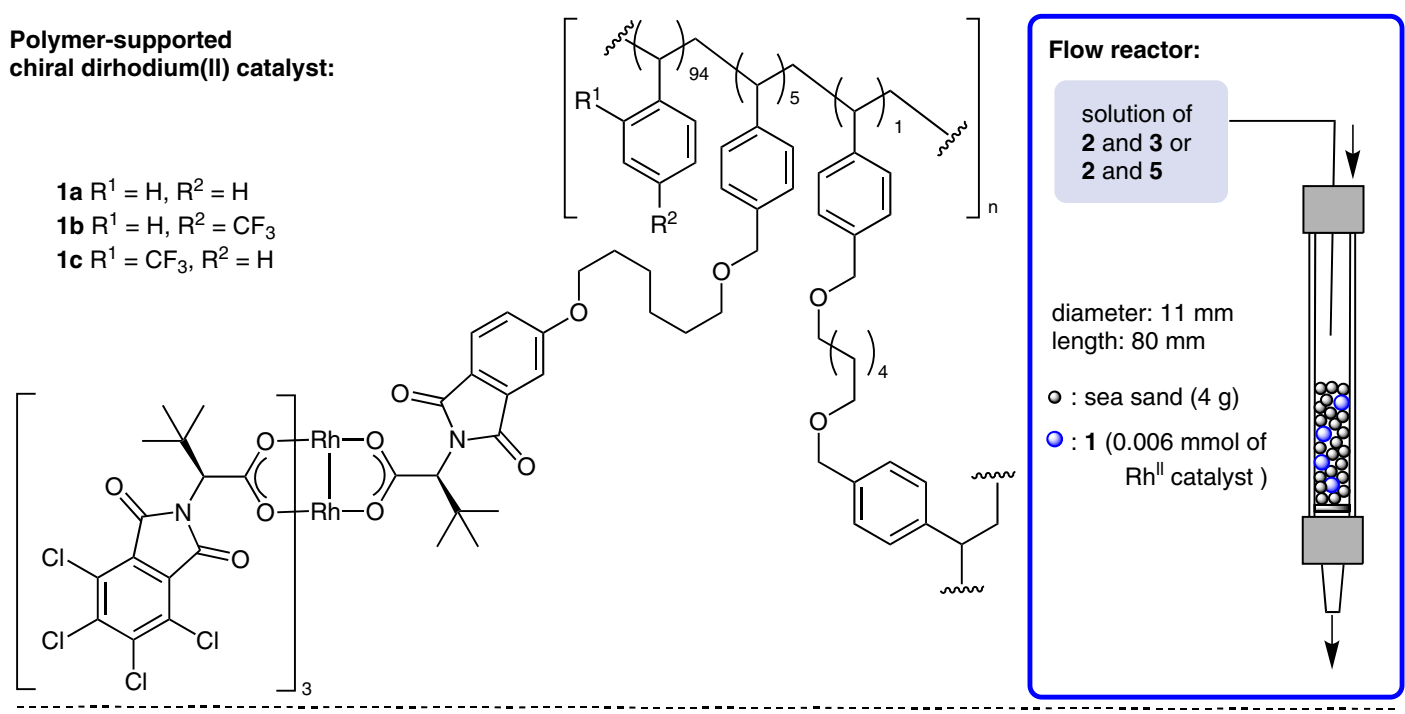

Enantioselective carbonyl ylide cycloaddition:<smiles>CCCOC(C(=O)CCC(=O)c1ccccc1)C1=NC1(C)C</smiles>
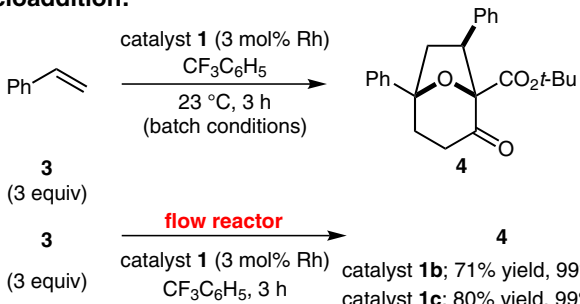

catalyst $1 \mathrm{a} ; 56 \%$ yield, $99 \%$ ee

catalyst 1 b; $64 \%$ yield, $99 \%$ catalyst 1 c; $69 \%$ yield, $99 \%$

$$
\begin{array}{ccc}
2 \mathbf{a} & & \mathbf{3} \\
(0.2 \mathrm{mmol}) & & (3 \text { equiv }) \\
\mathbf{2 a} & + & \mathbf{3} \\
(0.2 \mathrm{M}) & & \text { (3 equiv) }
\end{array}
$$

$$
\underset{\text { catalyst } 1(3 \mathrm{~mol} \% \mathrm{Rh})}{\stackrel{\text { flow reactor }}{\longrightarrow}}
$$

$\mathrm{CF}_{3} \mathrm{C}_{6} \mathrm{H}_{5}, 3 \mathrm{~h}$ catalyst $\mathbf{1 b} ; 71 \%$ yield, $99 \%$ ee

catalyst $1 \mathrm{c} ; 80 \%$ yield, $99 \%$ ee

$0.34 \mathrm{~mL} \mathrm{~h}^{-1}, 23{ }^{\circ} \mathrm{C} \quad$ catalyst $1 \mathrm{c} ; 0.5 \mathrm{~mL} \mathrm{~h}^{-1}, 60 \mathrm{~h}(0.1 \mathrm{~mol} \% \mathrm{Rh}) ; 78 \%$ yield, $99 \%$ ee

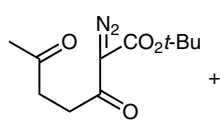

2b

$(0.2 \mathrm{M} ; 90 \mathrm{mmol})$

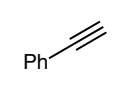

(3 equiv)

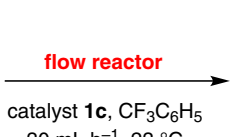
$30 \mathrm{~mL}^{-1}, 23^{\circ} \mathrm{C}$

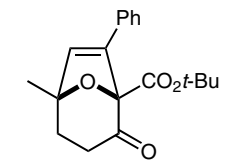

$0.1 \mathrm{~h}(1 \mathrm{~mol} \% \mathrm{Rh}) ; 75 \%$ yield, $98 \%$ ee $15 \mathrm{~h}(0.0067 \mathrm{~mol} \% \mathrm{Rh}) ; 78 \%$ yield, $97 \%$ ee

Significance: Polymer-supported chiral dirhodium(II) catalysts 1a-c were prepared and applied to the enantioselective carbonyl ylide cycloaddition under batch and flow conditions. Thus, the reaction of 2-diazo-3,6-diketo esters 2 with styrene (3) and phenylacetylene (5) was carried out with 1c to give the corresponding cycloadducts $\mathbf{4}$ and $\mathbf{6}$, respectively, in up to $80 \%$ yield and up to $99 \%$ ee.

\section{Gategory}

Polymer-Supported

Synthesis

\section{Key words}

asymmetric catalysis

continuous flow system

carbonyl ylide cycloaddition

rhodium

sYNFACTS Contributors: Yasuhiro Uozumi, Yoichi M. A. Yamada, Aya Ohn

Dol: 10.1055/s-0031-1290275; Reg-No.: Y00712SF

Comment: The flow reactor packed with 1c (0.1 mol\% Rh) and sea sand was used for the reaction of $\mathbf{2 a}$ and $\mathbf{3}$ to give $\mathbf{4}$ in $78 \%$ yield with 99\% ee (leaching of Rh: 2.1 ppm; 0.013\% of the initial catalyst charge). The flow reaction of $\mathbf{2} \mathbf{b}$ and 5 with $0.0067 \mathrm{~mol} \% \mathrm{Rh}$ of 1c afforded the cycloadduct $\mathbf{6}$ in $78 \%$ yield with $97 \%$ ee (TON $=11700$, $\left.\mathrm{TOF}=780 \mathrm{~h}^{-1}\right)$. 